Almeida, J.R.; Suguio, K.; Galvão, V. Vilas caiçaras de llha Comprida (SP): núcleos de proteção ambiental e desenvolvimento do Ecoturismo. Anais do VIII Congresso Nacional de Ecoturismo e do IV Encontro Interdisciplinar de Ecoturismo em Unidades de Conservação. Revista Brasileira de Ecoturismo, São Paulo, v.4, n.4, 2011, p. 524.

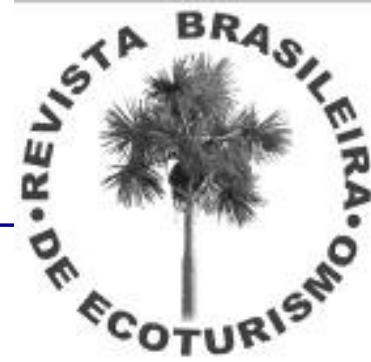

\title{
VILAS CAIÇARAS DE ILHA COMPRIDA (SP): NÚCLEOS DE PROTEÇÃO AMBIENTAL E DESENVOLVIMENTO DO ECOTURISMO
}

\author{
José Ricardo de Almeida*, Kenitiro Suguio**, Valdecir Galvão*** \\ *Universidade de Guarulhos, **Universidade de São Paulo, \\ ***Universidade Estadual Paulista Júlio de Mesquita Filho - Câmpus Rio Claro \\ E-mails: ricaecotur@ig.com.br, ricaterror@ig.com.br, braco_geo@yahoo.com.br
}

O município de Ilha Comprida, no Estado de São Paulo, transformou-se em um importante pólo de turismo de sol e praia. Atualmente, o numero de habitantes do município não atinge 10 mil, contudo a população flutuante é mais que decuplicada durante as férias escolares e feriados prolongados. Esses turistas, cujo interesse maior está voltado ao turismo de balneário, têm promovido freqüentes incursões ao interior da ilha, onde se situam ambientes naturais, tais como os manguezais, os sambaquis e as dunas eólicas. Esses atrativos quase sempre estão localizados nas proximidades das "Vilas Caiçaras", ou seja, vilas de pescadores de cultura tradicional, simples e rudimentar que ainda sobrevivem ao tempo, tendo como principal fonte de renda a pesca de subsistência e a retirada de crustáceos dos manguezais. O turismo tornou-se uma segunda opção de atividade econômica para essas comunidades, que prestam serviços como condutores turísticos, levando pessoas para passeios de barco, atravessando os canais de mangues ou guiando-os em visitações aos sambaquis e campos de dunas eólicas. Contudo falta apoio e planejamento para que essas comunidades possam padronizar sua forma de trabalho, criando um processo de conscientização ambiental para todos moradores locais, bem como para os turistas, transformando as vilas em núcleos de proteção ambiental, ou seja, base de apoio para as visitações turísticas aos ambientes e ecossistemas sensíveis. O objetivo do trabalho em questão é a criação de propostas para implementação do ecoturismo nas Vilas Caiçaras, desta forma, incrementando a atividade turística, criando também propostas de planejamento, no intuito de diminuir a degradação dos ecossistemas locais, fortalecendo uma alternativa socioeconômica viável, além disso, instituindo um trabalho conjunto integrando a comunidade, o poder público e os visitantes. Para alcançar o objetivo proposto foram necessários estudos bibliográficos sobre os ecossistemas locais, visando a caracterização, bem como a localização de tais ambientes. Posteriormente, realizaram-se as pesquisas em campo, ou seja, nas próprias Vilas Caiçaras, no intuito de verificar na prática as probabilidades de aplicação do turismo sustentável, além disso, foram consultados os órgãos responsáveis pela política local, tais como; prefeitura municipal, através dos departamentos de turismo, ecologia e pesca. As consultas bibliográficas contribuíram para uma melhor compreensão dos atrativos naturais caracterizados e nos trabalhos de campo verificou-se a localização privilegiada das vilas com relação a esses atrativos, constatou-se também a existência informal da atividade turística de base comunitária desenvolvida por pessoas das comunidades, confirmando o potencial desses locais para implantação de atividades de conscientização, voltadas principalmente ao valor cultural, educacional e paisagístico do município de Ilha Comprida

Palavras-chave: Vilas Caiçaras; Ilha Comprida; Ecoturismo. 